\title{
オーストラリア北西大陸棚に分布するジュラ系天然ガス貯留層 \\ Jurassic natural gas reservoir in the North West Shelf of Australia
}

$$
\text { 山本和幸*†・ジョーンズ トビー* }
$$

Kazuyuki Yamamoto ${ }^{* \dagger}$ and Toby Jones*

2021 年 6 月 2 日受付. 2021 年 9 月 23 日受理.

株式会社 INPEX パース事務所

INPEX Perth Office, 100 St Georges Terrace, Perth, WA 6000, Australia

現所属：株式会社 INPEX 技術本部

Present address: Technical Division, INPEX CORPORATION, Akasaka Biz Tower 5-3-1, Akasaka, Minato-ku, Tokyo 107-6332, Japan

Corresponding author; K. Yamamoto,

kazuyuki.yamamoto@inpex.co.jp

低炭素社会実現に向けた世界的な取り組みが加速する中, クリー ンエネルギーとしての天然ガスの重要性は大きく高まっている. オー ストラリア北西大陸棚に位置するイクシスガス・コンデンセート田 では、主力貯留層の一つであるジュラ系プローバー層に大規模な天 然ガスの胚胎が確認されており, 日本企業の操業主体による生産開 始に向け，実用的な貯留層モデルが構築されている (Yamamoto et al., 2020). 同層を貯留層とするガス田は同大陸棚に点在しており, 河川〜浅海の多様な堆積物が確認されている. さらに, ゴンドワナ 大陸の分裂に伴うジュラ紀火成岩の貫入・噴出が同貯留層の分布を 複雑にしている. 各ガス田で得られているコア試料は断片的な地質 情報であり, 実際の貯留層の分布・性状の不確実性を的確に評価す るためには, 広域的なコアデー夕の統合により, プローバー層の堆 積システム・灭成作用・埋没続成史を堆積盆スケールで包括的に理 解することが必要不可欠である.

Fig. 1. A) Location of the Ichthys Gas-Condensate Field and the gas export pipeline to Darwin in northwestern Australia (satellite image from Google Earth). The white dashed line indicates the outline of the Browse Basin (Longley et al., 2002). B) Simplified regional geological cross section of the Browse Basin (modified from Longley et al., 2002). The position of the cross section $(\mathrm{X}-\mathrm{Y})$ is shown in Fig. 1A. Note the distribution of the Plover Formation on the Triassic and Paleozoic basement.


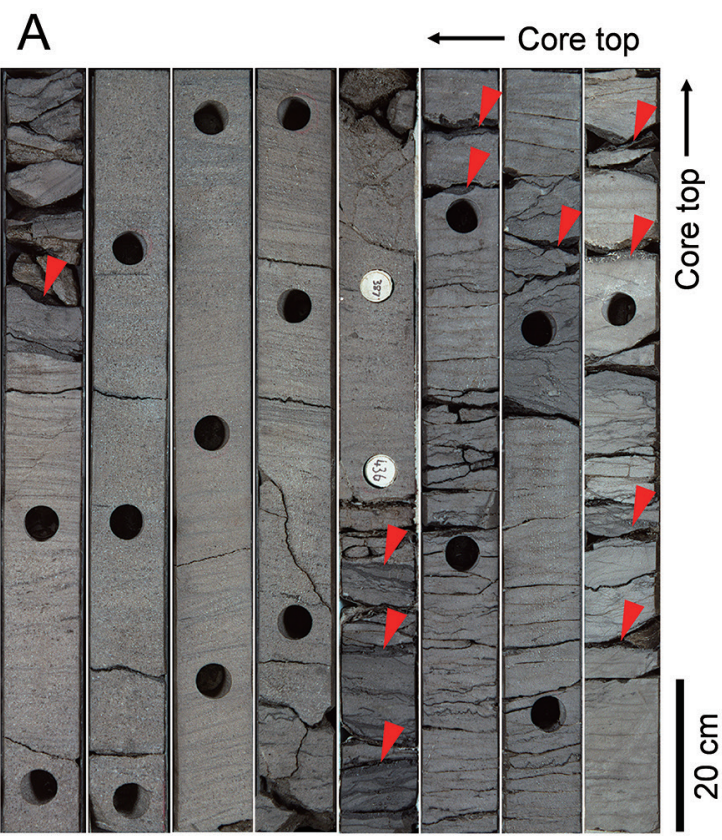

B

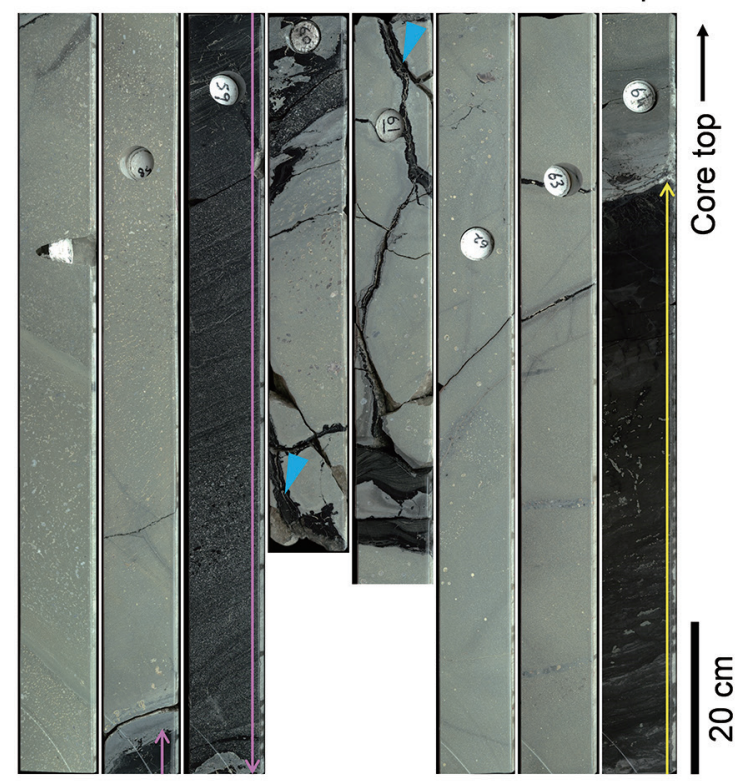

Fig. 2. Core photos showing the lithologies of the Plover Formation. A) Reservoir rock comprised of mainly medium- to coarse-grained fluvial channel sandstone showing massive to cross-bedded sedimentary structures. Red arrowheads mark thin coal layers. B) Non-reservoir rock consisting of weathered vesicular basalts interbedded with carbonaceous beds. The basalts are interpreted as sheet lava flows. Blue arrowheads mark injectites comprising carbonaceous sediment. A layer of volcaniclastic sandstone rich in carbonaceous material is marked by the pink line. The yellow line marks a layer of carbonaceous mudstone. These carbonaceous layers are thought to have been deposited in a coastal marsh environment. 

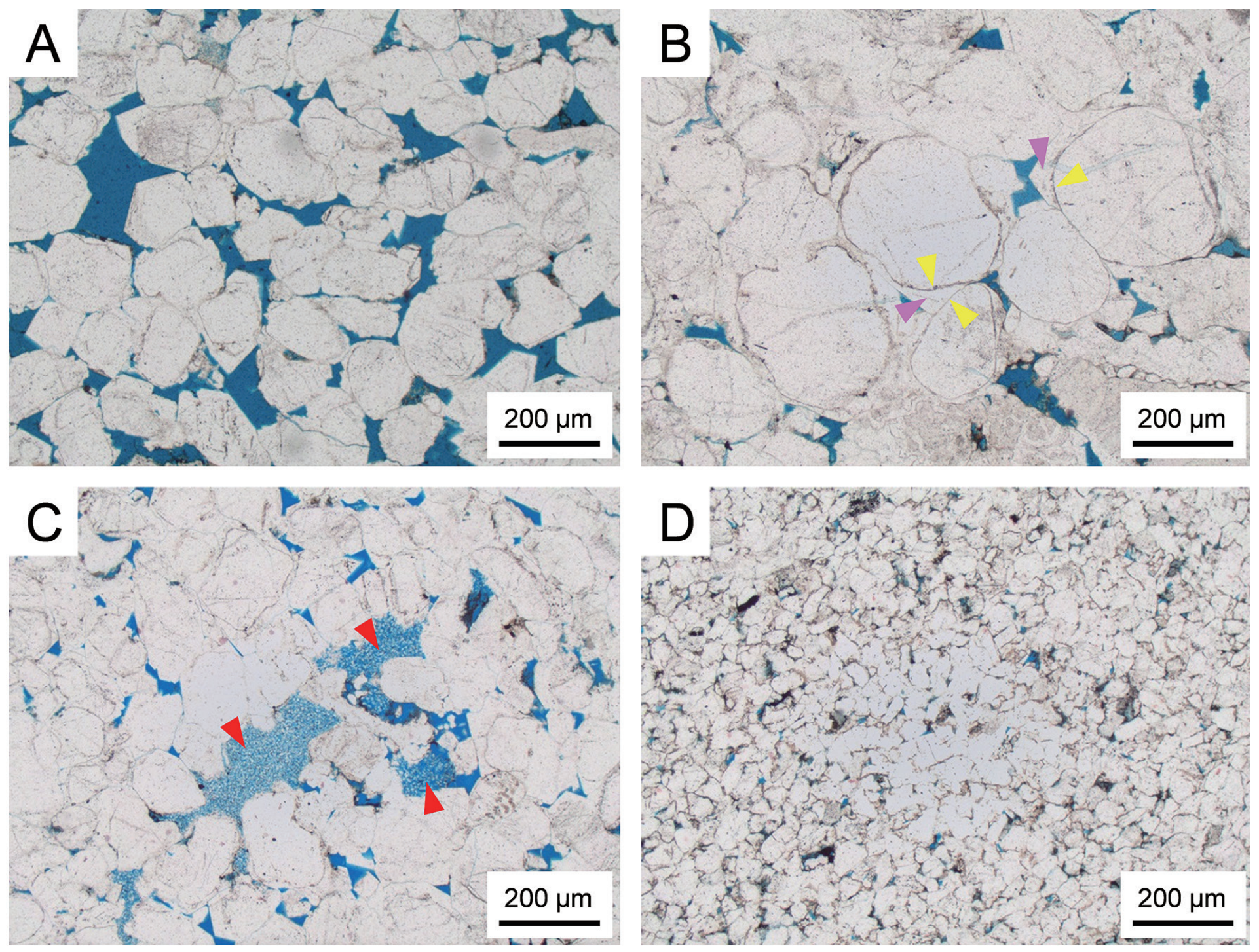

Fig. 3. Photomicrographs of the Plover Formation sandstone. Blue epoxy resin has been impregnated into rock samples to highlight the pore space. A) Clean fine-grained sandstone. B) Highly cemented medium-grained sandstone. Original grain surfaces are visible in some detrital quartz grains and are indicated by yellow arrowheads; pink arrowheads indicate quartz cement overgrowths. C) Patches of kaolinite clay occurring among the quartz grains (red arrowheads) are the product of the alteration of non-quartz grains (e.g., feldspars). The patches appear bluish because they contain porosity in the form of tiny pores in the interstices between the kaolinite crystals. D) Very fine-grained sandstone.

文献

Longley, I. M., Buessenschuett, C., Clydsdale, L., Cubitt, C. J., Davis, R. C., Johnson, M. K.,...Thompson, N. B., 2002, The North West Shelf of Australia - a Woodside perspective. In Keep, M. and Moss, S. J., eds., The Sedimentary Basins of Western Australia 3, Proc. Petrol. Explor. Soc. Australia Symp., Petrol. Explor. Soc. Australia, Perth, Western Australia, 27-88.

Yamamoto, K., Yamamoto, S., Jones, T., Iizuka, R., Maki, S., Yamatani, T.,...Seth, K., 2020, Reservoir characterisation and scenario-based modelling to optimise development planning of the Jurassic Plover Formation in the Ichthys Field, North West Shelf of Australia. SPE Asia Pac. Oil \& Gas Conf. Exhibition, SPE-202273-MS, Soc. Petrol. Eng., doi:10.2118/202273-MS.

\section{(著者貢献)}

山本：研究統括, 原稿執筆

ジョーンズ : コア・薄片観察, データ整理 